\title{
Sources of $\mathrm{Ca}^{2+}$ in relation to generation of acetylcholine- induced endothelium-dependent hyperpolarization in rat mesenteric artery
}

\author{
${ }^{1}$ Mitsuhiro Fukao, Yuichi Hattori, Morio Kanno, *Ichiro Sakuma \& *Akira Kitabatake \\ Departments of Pharmacology and *Cardiovascular Medicine, Hokkaido University School of Medicine, Sapporo 060, Japan
}

1 The aim of the present study was to identify the sources of $\mathrm{Ca}^{2+}$ contributing to acetylcholine (ACh)induced release of endothelium-derived hyperpolarizing factor (EDHF) from endothelial cells of rat mesenteric artery and to assess the pathway involved. The changes in membrane potentials of smooth muscles by ACh measured with the microelectrode technique were evaluated as a marker for EDHF release.

2 ACh elicited membrane hyperpolarization of smooth muscle cells in an endothelium-dependent manner. The hyperpolarizing response was not affected by treatment with $10 \mu \mathrm{M}$ indomethacin, $300 \mu \mathrm{M}$ $\mathrm{N}^{\mathrm{G}}$-nitro-L-arginine or $10 \mu \mathrm{M}$ oxyhaemoglobin, thereby indicating that the hyperpolarization is not mediated by prostanoids or nitric oxide but is presumably by EDHF.

3 In the presence of extracellular $\mathrm{Ca}^{2+}, 1 \mu \mathrm{M}$ ACh generated a hyperpolarization composed of the transient and sustained components. By contrast, in $\mathrm{Ca}^{2+}$-free medium, ACh produced only transient hyperpolarization.

4 Pretreatment with $100 \mathrm{nM}$ thapsigargin and $3 \mu \mathrm{M}$ cyclopiazonic acid, endoplasmic reticulum $\mathrm{Ca}^{2+}$ ATPase inhibitors, completely abolished ACh-induced hyperpolarization. Pretreatment with $20 \mathrm{~mm}$ caffeine also markedly attenuated ACh-induced hyperpolarization. However, the overall pattern and peak amplitude of hyperpolarization were unaffected by pretreatment with $1 \mu \mathrm{M}$ ryanodine.

5 In the presence of $5 \mathrm{mM} \mathrm{Ni}^{2+}$ or $3 \mathrm{mM} \mathrm{Mn}^{2+}$, the hyperpolarizing response to ACh was transient, and the sustained component of hyperpolarization was not observed. On the other hand, $1 \mu \mathrm{M}$ nifedipine had no effect on ACh-induced hyperpolarization.

6 ACh-induced hyperpolarization was nearly completely eliminated by $500 \mathrm{nM}$ U-73122 or $200 \mu \mathrm{M} 2-$ nitro-4-carboxyphenyl-N,N-diphenylcarbamate, inhibitors of phospholipase $\mathrm{C}$, but was unchanged by $500 \mathrm{nM}$ U-73343, an inactive form of U-73122. Pretreatment with $20 \mathrm{nM}$ staurosporine, an inhibitor of protein kinase $\mathrm{C}$, did not modify ACh-induced hyperpolarization.

7 These results indicate that the ACh-induced release of EDHF from endothelial cells of rat mesenteric artery is possibly initiated by $\mathrm{Ca}^{2+}$ release from inositol 1,4,5-trisphosphate $\left(\mathrm{IP}_{3}\right)$-sensitive $\mathrm{Ca}^{2+}$ pool as a consequence of stimulation of phospholipid hydrolysis due to phospholipase $\mathrm{C}$ activation, and maintained by $\mathrm{Ca}^{2+}$ influx via a $\mathrm{Ni}^{2+}$ - and $\mathrm{Mn}^{2+}$-sensitive pathway distinct from L-type $\mathrm{Ca}^{2+}$ channels. The $\mathrm{Ca}^{2+}$-influx mechanism seems to be activated following $\mathrm{IP}_{3}$-induced depletion of the pool.

Keywords: Acetylcholine; endothelium; hyperpolarization; endothelium-derived relaxing factor; calcium ion; vascular smooth muscle

\section{Introduction}

In a variety of blood vessels, acetylcholine (ACh) causes relaxations of smooth muscle cells indirectly by releasing some vasorelaxing mediators from the endothelium. These mediators include endothelium-derived nitric oxide (EDNO), prostacyclin $\left(\mathrm{PGI}_{2}\right)$ and endothelium-derived hyperpolarizing factor (EDHF) (Furchgott \& Vanhoutte, 1989; Suzuki et al., 1992; Garland et al., 1995). The release of EDNO and $\mathrm{PGI}_{2}$ from endothelial cells is believed to be triggered by an increase in cytosolic $\mathrm{Ca}^{2+}$ concentration $\left(\left[\mathrm{Ca}^{2+}\right]_{\mathrm{i}}\right)$ (Long \& Stone, 1985; Hallam et al., 1988).

However, in bovine cultured aortic endothelial cells EDNO release correlates most closely with transmembrane $\mathrm{Ca}^{2+}$ influx rather than $\mathrm{Ca}^{2+}$ release from intracellular pools, while $\mathrm{PGI}_{2}$ release is entirely dependent on $\mathrm{Ca}^{2+}$ release from the pools (Lückhoff et al., 1988). Parsaee et al. (1992) have shown that higher levels of $\left[\mathrm{Ca}^{2+}\right]_{\mathrm{i}}$ are required for $\mathrm{PGI}_{2}$ release than for EDNO release. Furthermore, inhibition of intracellular $\mathrm{Ca}^{2+}$ mobilization by TMB-8 attenuated bradykinin-induced $\mathrm{PGI}_{2}$ release (Whorton et al., 1987), while exerting a minimal effect on EDNO release (Peach et al., 1984). Thus, there is a difference in $\mathrm{Ca}^{2+}$ sources required for the release of EDNO and $\mathrm{PGI}_{2}$.

${ }^{1}$ Author for correspondence.
The elevation of $\left[\mathrm{Ca}^{2+}\right]_{\mathrm{i}}$ in endothelial cells has been also proposed to be essential for the release of EDHF (Chen \& Suzuki, 1990). This hypothesis has been supported by the findings that the $\mathrm{Ca}^{2+}$-ionophore A23187 induces endothelium-dependent membrane hyperpolarization (Chen \& Suzuki, 1990; Nagao \& Vanhoutte, 1992; Nakashima \& Vanhoutte, 1993). However, the involvement of either transmembrane $\mathrm{Ca}^{2+}$ influx, as EDNO, or $\mathrm{Ca}^{2+}$ release from intracellular pools, as $\mathrm{PGI}_{2}$ for EDHF release remains questionable.

The elevation of $\left[\mathrm{Ca}^{2+}\right]_{\mathrm{i}}$ in endothelial cells induced by agonists such as $\mathrm{ACh}$ is the result of both $\mathrm{Ca}^{2+}$ release from intracellular stores and transmembrane $\mathrm{Ca}^{2+}$ influx through non-voltage-gated channels (Newby \& Henderson, 1990). The release of $\mathrm{Ca}^{2+}$ from intracellular stores is mainly initiated by inositol 1,4,5-trisphosphate $\left(\mathrm{IP}_{3}\right)$, which is generated from phosphatidylinositol 4,5-bisphosphate breakdown by phospholipase $\mathrm{C}$ upon activation of the receptor with agonist, but a caffeine-sensitive $\mathrm{Ca}^{2+}$-induced $\mathrm{Ca}^{2+}$ release mechanism may contribute to the release of $\mathrm{Ca}^{2+}$ to lesser extent (Lesh et al., 1993). The release of $\mathrm{Ca}^{2+}$ from intracellular stores is generally accompanied by transmembrane $\mathrm{Ca}^{2+}$ influx (Berridge, 1993). The linkage between these two events is intriguingly proposed as the capacitative model (Putney, 1986) in that transmembrane $\mathrm{Ca}^{2+}$ influx is controlled by the extent of filling of in- 
tracellular $\mathrm{Ca}^{2+}$ stores. Recent evidence suggests that depletion of intracellular $\mathrm{Ca}^{2+}$ stores may trigger $\mathrm{Ca}^{2+}$ influx through a novel messenger named ' $\mathrm{Ca}^{2+}$-influx factor' (Randriamampita $\&$ Tsien, 1993). Other results imply that $\mathrm{Ca}^{2+}$ influx may be a direct consequence of receptor activation (Xiong et al., 1991; Graier et al., 1992), or it may result from agonist-induced formation of 1,3,4,5-tetrakisphosphate $\left(\mathrm{IP}_{4}\right)$ (Lückhoff \& Clapham, 1992). It remains to be elucidated which of the above-mentioned putative mechanisms for agonist-induced increases in $\left[\mathrm{Ca}^{2+}\right]_{\mathrm{i}}$ in endothelial cells play a key role in EDHF release.

This study focused on clarifying which is the more important source of $\mathrm{Ca}^{2+}$ for ACh-induced release of EDHF, $\mathrm{Ca}^{2+}$ released from intracellular stores or $\mathrm{Ca}^{2+}$ influxed from the extracellular medium. We measured ACh-induced endothelium-dependent hyperpolarization in rat mesenteric artery as a marker for EDHF release. We examined how AChinduced hyperpolarization is modified by $\mathrm{Ca}^{2+}$ removal from the extracellular medium and by the substances acting on intracellular $\mathrm{Ca}^{2+}$ stores or transmembrane $\mathrm{Ca}^{2+}$ influx. In order to determine whether EDHF release is linked to ACh-induced stimulation of phospholipase $\mathrm{C}$ and subsequent activation of protein kinase $\mathrm{C}$, the effects of the inhibitors of phospholipase $\mathrm{C}$ and protein kinase $\mathrm{C}$ on $\mathrm{ACh}$-induced hyperpolarization were also examined.

\section{Methods}

Male Wistar rats, 250-350 g, were anaesthetized with diethyl ether. The main branch of the superior mesenteric arteries (diameter; average $0.98 \mathrm{~mm}$ ) was carefully removed and cleaned of the surrounding fat and connective tissue in oxygenated physiological salt solution (PSS) at room temperature. The artery was cut into rings, $3-\mathrm{mm}$ in length, opened longitudinally and mounted on a chamber (capacity $3 \mathrm{ml}$ ) with tiny pins with endothelial side facing up. The tissue was superfused with warmed $\left(37^{\circ} \mathrm{C}\right)$ PSS aerated with $95 \% \mathrm{O}_{2}$ and $5 \% \mathrm{CO}_{2}$ at a constant flow rate of $7 \mathrm{ml} \mathrm{min} \mathrm{m}^{-1}$ and allowed to equilibrate for at least $60 \mathrm{~min}$ before the start of recordings. Where indicated, the endothelial cells was removed by gently rubbing the intimal surface of the vessel with a moistened cotton ball. Glass capillary microelectrodes filled with $3 \mathrm{M} \mathrm{KCl}$ (tip resistances $40-80 \mathrm{M} \Omega$ ) were impaled into the smooth muscle cells from the intimal side. The microelectrode was coupled by a $\mathrm{Ag} / \mathrm{AgCl}$ junction to a high impedance capacitance neutralizing amplifier (Nihon Kohden, MEZ-8201, Tokyo, Japan). An agar bridge containing $3 \mathrm{M} \mathrm{KCl}$ was used as a reference electrode. Electrical signals were continuously monitored on a oscilloscope (Nihon Kohden, VC-10, Tokyo, Japan) and recorded on a chart recorder (Watanabe Sokki WR3101, Tokyo, Japan). After a stable membrane potential for at least $2 \mathrm{~min}$, application of $\mathrm{ACh}$ was commenced. We compared the hyperpolarizing responses to $\mathrm{ACh}$ before and after application of various interventions. When the tissues were pretreated with the drugs, they were added to the medium 15-25 min before the second challenge with ACh. We confirmed that repeated determinations did not affect the overall pattern of the hyperpolarizing response to $\mathrm{ACh}$ if the second challenge with ACh was given at 5 min or more after the first challenge.

The composition of PSS was as follows (in $\mathrm{mM}$ ): $\mathrm{NaCl} 118.2$, $\mathrm{KCl}$ 4.7, $\mathrm{CaCl}_{2} 2.5, \mathrm{MgCl}_{2} 1.2, \mathrm{KH}_{2} \mathrm{PO}_{4} 1.2, \mathrm{NaHCO}_{3} 25.0$ and glucose 10.0. For $\mathrm{Ca}^{2+}$-free PSS, $\mathrm{Ca}^{2+}$ was omitted and $0.2 \mathrm{mM}$ EGTA was added. When $\mathrm{NiCl}_{2}$ or $\mathrm{MnCl}_{2}$ was used, $\mathrm{HCO}_{3}{ }^{-}$was substituted by HEPES-NaOH. The HEPES solution was gassed with $100 \% \mathrm{O}_{2}$ and the $\mathrm{pH}$ of the solution was adjusted to 7.4. The composition of the HEPES solution was as follows (in $\mathrm{mM}$ ); $\mathrm{NaCl} 143.0, \mathrm{KCl} 5.4, \mathrm{CaCl}_{2} 2.5, \mathrm{MgCl}_{2} 0.5$, $\mathrm{NaH}_{2} \mathrm{PO}_{4}$ 0.33, HEPES 5 and glucose 5.5.

The following drugs were used: ACh chloride, caffeine, staurosporine and 3-isobutyl-1-methyl-xanthine (IBMX) (Wako, Osaka, Japan); thapsigargin (TSG) (Calbiochem-No- vabiochem, San Diego, CA, U.S.A.); U-73122 (1-(6-((17 $\beta-3-$ methoxyestra-1,3,5(10)-trien-17-yl)amino)hexyl) - 1H - pyrrole2,5-dione) and U-73343 (1-(6-((17)-3-methoxyestra-1,3,5(10)trien - 17 - yl)amino)hexyl) -2,5 - pyrrolidine-dione) (BIOMOL Research, Plymouth Meeting, PA, U.S.A.); ryanodine (Progressive Agri Systems, Wind Gap, PA, U.S.A.); pinacidil (Shionogi, Osaka, Japan); and indomethacin, $\mathrm{N}^{\mathrm{G}}$-nitro-L-arginine (L-NOARG), cyclopiazonic acid (CPA), 2-nitro-4-carboxyphenyl-N,N-diphenylcarbamate (NCDC) and nifedipine (Sigma Chemical, St. Louis, MO, U.S.A.). ACh was dissolved in distilled water. Staurosporine, ryanodine, caffeine, CPA, U73122, U-73343, IBMX and indomethacin were dissolved in dimethyl sulphoxide. TSG and NCDC were prepared in dimethyl sulphoxide and diluted in ethanol. Pinacidil and LNOARG were dissolved in $0.2 \mathrm{~N} \mathrm{HCl}$. Nifedipine was dissolved in ethanol. Further dilutions were made with PSS. Oxyhaemoglobin was prepared according to the method of Martin et al. (1985). The experiments with nifedipine were performed in the dark.

All values are expressed as the means \pm s.e.mean. For statistical evaluation, Student's paired $t$ test was used. Values of $P<0.05$ were considered significant.

\section{Results}

\section{Endothelium-dependent hyperpolarization by ACh}

Resting membrane potential of the mesenteric arterial smooth muscle cells were $-53.2 \pm 0.5 \mathrm{mV}(n=85)$. In tissues with endothelium, $1 \mu \mathrm{M}$ ACh hyperpolarized the membrane potential by $-15.8 \pm 0.3 \mathrm{mV}(n=64)$. In tissues without endothelium, ACh produced no significant change in the membrane potential (Figure 1a). Treatment with $10 \mu \mathrm{M}$ indomethacin, $300 \mu \mathrm{M}$ L-NOARG or $10 \mu \mathrm{M}$ oxyhaemoglobin did not affect the resting membrane potentials or ACh-induced membrane hyperpolarizations (Figure $1 \mathrm{~b}-\mathrm{d}$ ).

\section{Extracellular $\mathrm{Ca}^{2+}$ and ACh-induced hyperpolarization}

As described previously (Fukao et al., 1995a), the hyperpolarizing response to $\mathrm{ACh}$ was composed of two components; i.e., an initial transient component followed by a sustained one. In most of the preparations, the initial transient component smoothly merged in the sustained one. Occasionally, a brief depolarizing notch helped to separate these components. The initial component appeared immediately after the addition, reaching a maximum level within $10 \mathrm{~s}$. The sustained component following the initial component reached a maximum level about $60 \mathrm{~s}$ later, and decayed with a very slow time course.

When the preparations were exposed to $\mathrm{Ca}^{2+}$-free PSS, the resting membrane potentials gradually depolarized. The membrane potentials were depolarized by $6.2 \pm 0.9$ and $13.5 \pm 2.1$ $\mathrm{mV}(n=6)$ at 5 and $10 \mathrm{~min}$ after exposure to $\mathrm{Ca}^{2+}$-free PSS, respectively. In $\mathrm{Ca}^{2+}$-free PSS, ACh produced only a transient hyperpolarization lasting for about $1 \mathrm{~min}$ (Figure 2). The peak amplitude of hyperpolarization was $-15.2 \pm 1.1 \mathrm{mV}(n=6)$. Five min after the initial application of $\mathrm{ACh}$ in $\mathrm{Ca}^{2+}$-free PSS, subsequent application of $\mathrm{ACh}$ produced virtually no hyperpolarization (Figure 2). The membrane potentials were repolarized to the original level $5 \mathrm{~min}$ after the reintroduction of normal PSS. Then application of ACh produced sustained hyperpolarization that was almost similar to the control response, but the initial component of hyperpolarization only partially recovered (Figure 2). The same hyperpolarizing response to $\mathrm{ACh}$ as the control one was observed $10 \mathrm{~min}$ after the reintroduction of PSS containing normal $\mathrm{Ca}^{2+}$ (data not shown).

\section{Intracellular $\mathrm{Ca}^{2+}$ stores and ACh-induced hyperpolarization}

TSG and CPA reduce intracellular $\mathrm{Ca}^{2+}$ stores by inhibiting the $\mathrm{Ca}^{2+}$-pump ATPase of the endoplasmic reticulum 
(Georger et al., 1988; Seidler et al., 1989; Thastrup et al., 1990). As demonstrated in our previous study (Fukao et al., 1995a), TSG and CPA elicited endothelium-dependent hyperpolarization. When $100 \mathrm{~nm}$ TSG and $3 \mu \mathrm{M} \mathrm{CPA}$ were applied, the

a

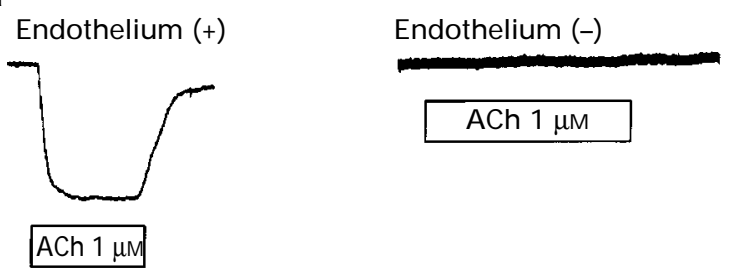

b

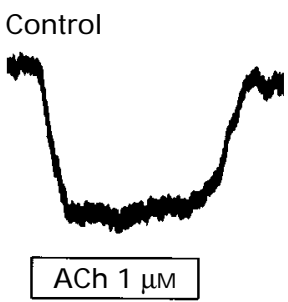

Indomethacin $10 \mu \mathrm{m}$

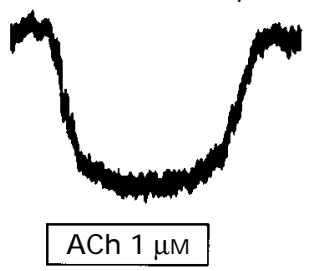

C

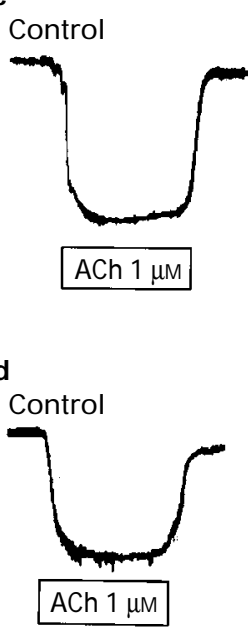

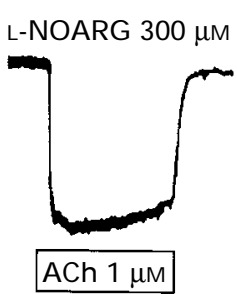

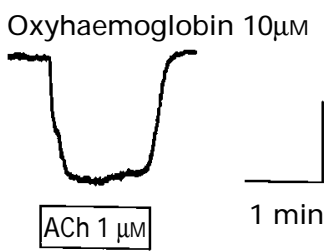

$10 \mathrm{mV}$

membrane potentials were hyperpolarized by $-11.7 \pm 1.0 \mathrm{mV}$ $(n=6)$ and $-11.7 \pm 1.9 \mathrm{mV}(n=6)$, respectively. In spite of the continuous presence of TSG or CPA, the membrane potential returned to the resting level with a very slow time course. After the membrane potential had nearly reversed to the resting level (usually $20 \mathrm{~min}$ ), application of $1 \mu \mathrm{M}$ ACh failed to produce any detectable change in the membrane potentials (Figure 3a and b). Thus, pretreatment with TSG and CPA completely blocked ACh-induced hyperpolarization. In contrast, the hyperpolarizing response induced by pinacidil, a ATP-sensitive $\mathrm{K}^{+}$channel opener, was not inhibited by pretreatment with TSG and CPA (Figure 3c).

Caffeine initially enhances the release of $\mathrm{Ca}^{2+}$ from intracellular stores and subsequently inhibits $\mathrm{Ca}^{2+}$ uptake, thereby depleting the stores (Weber \& Herz, 1968). The changes in the membrane potential induced by $20 \mathrm{~mm}$ caffeine were usually biphasic. Thus, caffeine produced a transient hyperpolarizing effect $(-6.3 \pm 1.1 \mathrm{mV}, n=6)$ followed by a sustained depolarizing effect $(10.2 \pm 1.4 \mathrm{mV}, n=6)$. In the presence of $20 \mathrm{~mm}$ caffeine, the hyperpolarizing response to $1 \mu \mathrm{M}$ ACh was nearly completely eliminated (Figure 4a). The peak amplitude of hyperpolarization was $-16.6 \pm 0.6$ and $-0.7 \pm 0.3 \mathrm{mV}(n=6)$ before and after treatment with caffeine, respectively. Because caffeine also acts as a phosphodiesterase inhibitor (Leijten \& van Breemen, 1984), we examined the effect of phosphodiesterase inhibitor IBMX on ACh-induced hyperpolarization. IBMX significantly attenuated ACh-in-

a

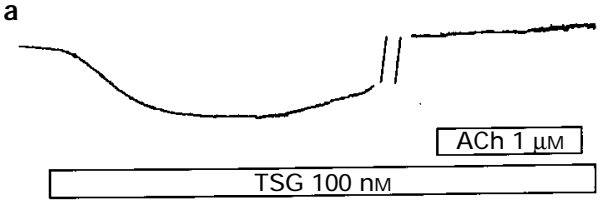

b

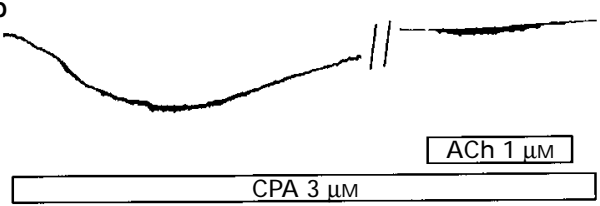

c

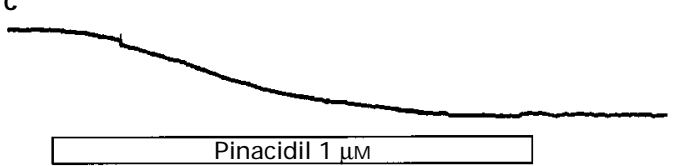

Figure 1 Effects of endothelium removal (a), $10 \mu \mathrm{M}$ indomethacin (b), $300 \mu \mathrm{M}$ L-NOARG (c) and $10 \mu \mathrm{M}$ oxyhaemoglobin (d) on membrane hyperpolarization induced by $1 \mu \mathrm{M} \mathrm{ACh}$ in rat mesenteric artery. Indomethacin, L-NOARG, oxyhaemoglobin were added to the bath $15-25 \mathrm{~min}$ before ACh. Removal of endothelium, indomethacin, L-NOARG or oxyhaemoglobin had no effect on the resting membrane potentials.

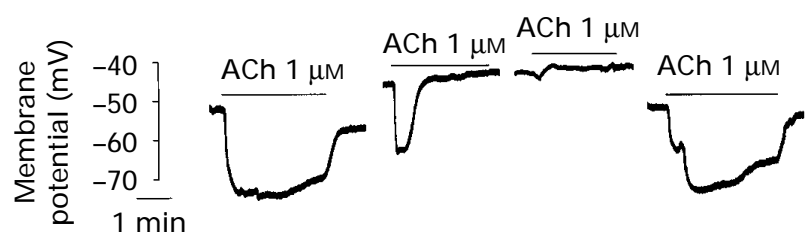

$\mathrm{Ca}^{2+} 2.5 \mathrm{~mm} \mathrm{Ca}^{2+}$-free (EGTA $\left.0.2 \mathrm{~mm}\right) \mathrm{Ca}^{2+} 2.5 \mathrm{~mm}$

Figure 2 Effect of extracellular $\mathrm{Ca}^{2+}$ concentrations on AChinduced hyperpolarization in rat mesenteric artery. Initially, $1 \mu \mathrm{M}$ ACh was applied in normal PSS. Then, the tissue was exposed to $\mathrm{Ca}^{2+}$-free PSS and ACh was applied with an interval of $5 \mathrm{~min}$. Subsequently, the response to ACh was obtained $5 \mathrm{~min}$ after the reintroduction of normal PSS.
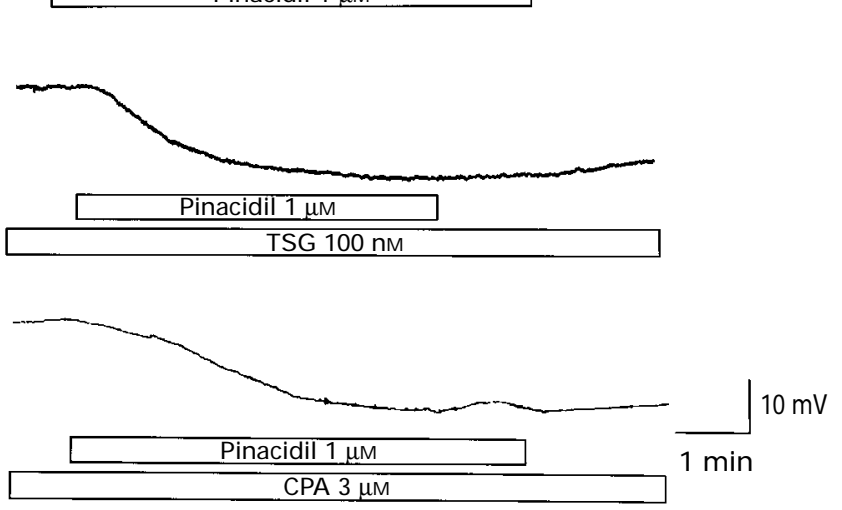

Figure 3 Effects of (a) thapsigargin (TSG) and (b) cyclopiazonic acid (CPA) on cell membrane potential and ACh-induced hyperpolarization and (c) on pinacidil-induced hyperpolarization in rat mesenteric artery. (a and b) Application of $100 \mathrm{~nm}$ TSG or $3 \mu \mathrm{M} \mathrm{CPA}$ produced hyperpolarization. After pretreatment with TSG or CPA for $20 \mathrm{~min}$, the hyperpolarizing response to $1 \mu \mathrm{m} \mathrm{ACh}$ was abolished. (c) Pinacidil elicited endothelium-independent hyperpolarization of the smooth muscle cells. Pretreatment with TSG or CPA had no effect on pinacidil-induced hyperpolarization. 
duced hyperpolarization; the peak amplitude of the hyperpolarizing response to $1 \mu \mathrm{M} \mathrm{ACh}$ was $-17.6 \pm 1.5$ and $-9.2 \pm 4.0 \mathrm{mV}(n=5, P<0.05)$ before and after treatment with $500 \mu \mathrm{M}$ IBMX, respectively.

Ryanodine depletes intracellular $\mathrm{Ca}^{2+}$ stores by opening $\mathrm{Ca}^{2+}$ release channels and making the endoplasmic reticulum leaky to $\mathrm{Ca}^{2+}$ (Hwang \& van Breemen, 1987). Figure 4b shows the hyperpolarizing response to $1 \mu \mathrm{M} \mathrm{ACh}$ before and after treatment with $1 \mu \mathrm{M}$ ryanodine. Ryanodine had no effect on the resting membrane potential (before: $-53.7 \pm 1.8$, after $-53.5 \pm 2.2, n=6$ ). Furthermore, the overall pattern of AChinduced hyperpolarization was unchanged in the presence of ryanodine. The peak amplitude of hyperpolarization was $-15.8 \pm 0.5$ and $-16.0 \pm 0.6 \mathrm{mV}(n=6)$ before and after treatment with $1 \mu \mathrm{M}$ ryanodine, respectively. Even when ex-

a

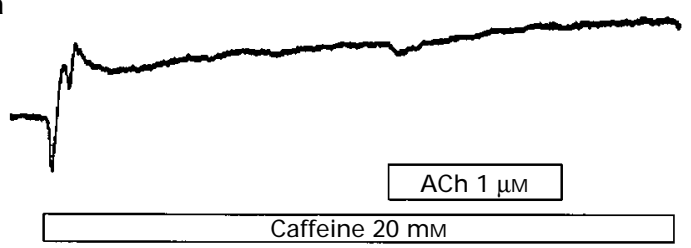

b

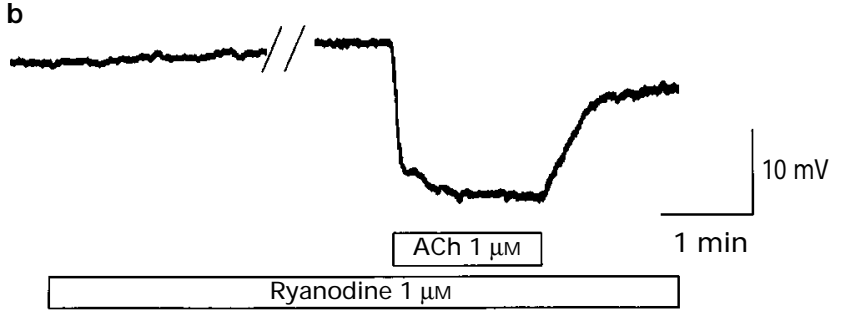

Figure 4 Effects of (a) caffeine and (b) ryanodine on cell membrane potential and ACh-induced hyperpolarization in rat mesenteric artery. Application of $20 \mathrm{~mm}$ caffeine caused transient hyperpolarization followed by sustained depolarization, but $1 \mu \mathrm{M}$ ryanodine produced no significant change in membrane potential. The hyperpolarizing response to $1 \mu \mathrm{M} \mathrm{ACh}$ was eliminated $5 \mathrm{~min}$ after exposure to caffeine. Treatment with ryanodine for $15 \mathrm{~min}$ had no significant effect on the response to ACh.

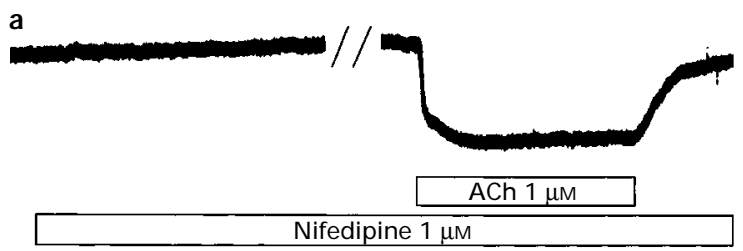

b

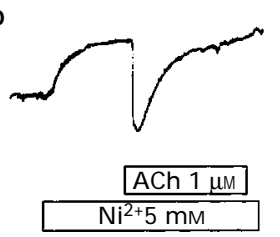

c

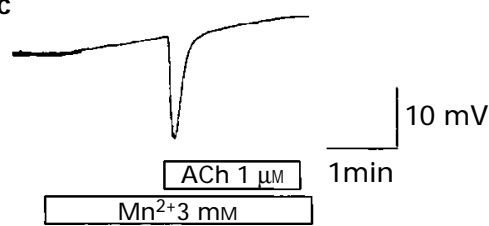

Figure 5 Effects of (a) nifedipine, (b) $\mathrm{Ni}^{2+}$ and (c) $\mathrm{Mn}^{2+}$ on cell membrane potential and $\mathrm{ACh}$-induced hyperpolarization in rat mesenteric artery. Application of $1 \mu \mathrm{M}$ nifedipine had no effect on membrane potential, and the hyperpolarizing response to $1 \mu \mathrm{M} \mathrm{ACh}$ was unaffected by its treatment for $15 \mathrm{~min}$. Membrane potentials were depolarized by $5 \mathrm{mM} \mathrm{Ni}^{2+}$ and $3 \mathrm{mM} \mathrm{Mn}^{2+}$. In the presence of $\mathrm{Ni}^{2+}$ or $\mathrm{Mn}^{2+}$, the hyperpolarizing response to ACh was transient. The experiments with $\mathrm{Ni}^{2+}$ and $\mathrm{Mn}^{2+}$ were performed in HEPES solution. posed to a higher concentration of ryanodine $(10 \mu \mathrm{M})$, the hyperpolarizing response to $\mathrm{ACh}$ was unaffected (data not shown).

\section{Inhibition of transmembrane $\mathrm{Ca}^{2+}$ influx and $\mathrm{ACh}$ - induced hyperpolarization}

Figure 5a shows the effect of the dihydropyridine $\mathrm{Ca}^{2+}$ channel antagonist nifedipine on ACh-induced hyperpolarization. The resting membrane potential was unaltered by treatment with $1 \mu \mathrm{M}$ nifedipine (before: $-54.0 \pm 1.9$, after: $-54.2 \pm 1.2, n=6$ ). Nifedipine did not alter the overall pattern of hyperpolarization produced by $1 \mu \mathrm{M}$ ACh. The peak amplitudes of hyperpolarization were the same before and after treatment with nifedipine $(-16.3+1.1$ and $-16.8+0.9 \mathrm{mV}, n=6)$.

$\mathrm{Ca}^{2+}$ antagonistic cations $\mathrm{Ni}^{2+}$ and $\mathrm{Mn}^{2+}$ caused sustained depolarization of the membrane. The amplitudes of depolarization (measured at the peak) produced by $5 \mathrm{mM} \mathrm{Ni}^{2+}$ and $3 \mathrm{mM} \mathrm{Mn}^{2+}$ were $4.5 \pm 1.2(n=6)$ and $2.6 \pm 0.7 \mathrm{mV}(n=6)$, respectively. In the experiments with $\mathrm{Ni}^{2+}$ and $\mathrm{Mn}^{2+}$, the HEPES solution was used in order to prevent precipitation. The hyperpolarizing response to $1 \mu \mathrm{M}$ ACh remained unchanged in the HEPES solution: the peak of hyperpolarization was $-17.2 \pm 0.8 \mathrm{mV}(n=12)$ in the HEPES solution. However, in the presence of $\mathrm{Ni}^{2+}$ or $\mathrm{Mn}^{2+}$, ACh produced only transient hyperpolarization and the sustained component of hyperpolarization was not generated (Figure $5 b$ and c).

\section{Effects of phospholipase $C$ and protein kinase $C$ inhibitors on ACh-induced hyperpolarization}

As shown in Figure 6a, $500 \mathrm{~nm}$ U-73122, a phospholipase C inhibitor (Smith et al., 1989), nearly completely inhibited the hyperpolarizing response to $1 \mu \mathrm{M} \mathrm{ACh}$ without affecting the resting membrane potential. Another phospholipase $\mathrm{C}$ inhibitor, NCDC $200 \mu \mathrm{M}$ (Walenga et al., 1980), also abolished ACh-induced hyperpolarization $(n=6)$. On the other hand, in the presence of $500 \mathrm{nM} \mathrm{U}-73343$, an inactive form of U-73122 (Smith et al., 1989), ACh elicited hyperpolarization in a manner similar to the response obtained before its treatment (Figure 6b). U-73122 did not affect membrane hyperpolarization induced by pinacidil (data not shown).

The effect of $20 \mathrm{~nm}$ staurosporine, a putative protein kinase C inhibitor (Tamaoki et al., 1986), on ACh-induced hyperpolarization was also tested. Pretreatment with staur-

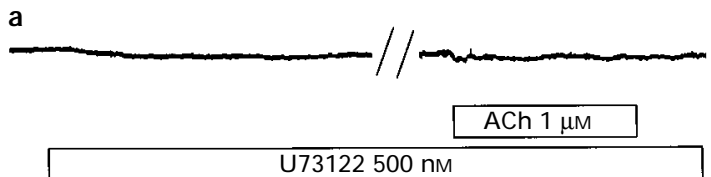

b

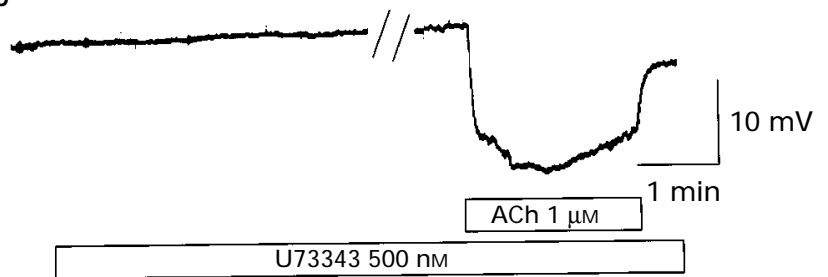

Figure 6 Modulation by (a) U-73122 and (b) U-73343 of AChinduced hyperpolarization in rat mesenteric artery. Application of $500 \mathrm{~nm} \mathrm{U-73122} \mathrm{or} 500 \mathrm{~nm}$ U-73343 produced no change in membrane potential. The hyperpolarizing response to $1 \mu \mathrm{M} \mathrm{ACh}$ was abolished by U-73122 but unaffected by U-73343. A pretreatment period of at least 15 min was allowed before challenge with ACh. 
osporine had no effect on the overall pattern of hyperpolarization produced by $1 \mu \mathrm{M}$ ACh. The peak amplitude of hyperpolarization was $-16.2 \pm 0.1$ and $-16.0 \pm 0.9 \mathrm{mV}(n=6)$ before and after treatment with staurosporine, respectively.

\section{Discussion}

As demonstrated in our previous study (Fukao et al., 1995a), $\mathrm{ACh}$ caused endothelium-dependent hyperpolarization in rat mesenteric artery. ACh-induced hyperpolarization was not affected by pretreatment with $300 \mu \mathrm{M}$ L-NOARG, which can almost completely inhibit NO synthase activity in endothelial cells (Moore et al., 1990). Oxyhaemoglobin, which inhibits NO-mediated responses by scavenging $\mathrm{NO}$, had no effect on ACh-induced hyperpolarization. In addition, there are several studies showing that exogenous NO is unable to produce hyperpolarization in blood vessels in which endothelium-dependent hyperpolarization is observed (Bény \& Brunet, 1988; Brayden, 1990; Komori et al., 1988). Pretreatment with indomethacin also had no effect on ACh-induced hyperpolarization. Hence, it is reasonable to conclude that endotheliumdependent hyperpolarization produced by $\mathrm{ACh}$ in rat mesenteric artery is not mediated by EDNO or prostanoids but is presumably by EDHF

The present results confirm our previous findings that AChinduced endothelium-dependent hyperpolarization in rat mesenteric artery is composed of two components differing in the time course and dependency on extracellular $\mathrm{Ca}^{2+}$ (Fukao et al., 1995a). This observation is also consistent with the results of Chen \& Suzuki (1990) obtained in the rabbit carotid artery. The transient component of ACh-induced hyperpolarization was less sensitive to extracellular $\mathrm{Ca}^{2+}$ than the sustained component. The two components were clearly distinguishable during the course of the reintroduction of the medium having normal $\mathrm{Ca}^{2+}$. In cultured endothelial cells, the increase in $\left[\mathrm{Ca}^{2+}\right]_{\mathrm{i}}$ elicited by agonists such as ACh and bradykinin also consists of two components, and only the transient increase in $\left[\mathrm{Ca}^{2+}\right]_{\mathrm{i}}$ is generated in $\mathrm{Ca}^{2+}$-free medium (Hallam \& Person, 1986; Colden-Stanfield et al., 1987; Danthuluri et al., 1988). In addition, the $\mathrm{Ca}^{2+}$ ionophore A23187 can induce endotheliumdependent hyperpolarization (Chen \& Suzuki, 1990; Nagao \& Vanhoutte, 1992; Nakashima \& Vanhoutte, 1993). Therefore, it appears likely that the increased $\left[\mathrm{Ca}^{2+}\right]_{\mathrm{i}}$ would trigger a release of EDHF from endothelial cells, thereby leading to endothelium-dependent hyperpolarization of smooth muscle cells. Thus, the increase in $\left[\mathrm{Ca}^{2+}\right]_{i}$ in endothelial cells seems to have a crucial role in EDHF release.

When extracellular $\mathrm{Ca}^{2+}$ was removed, ACh generated only a transient hyperpolarizing response, indicating that EDHF causing the transient hyperpolarization is highly dependent on $\mathrm{Ca}^{2+}$ released from intracellular stores. This $\mathrm{Ca}^{2+}$ release from intracellular stores is presumably due to an increase in intracellular $\mathrm{IP}_{3}$ following $\mathrm{ACh}$ stimulation. As demonstrated in a variety of cells (Nathanson, 1987), stimulation of muscarinic receptors with $\mathrm{ACh}$ accelerates the hydrolysis of inositol phospholipids via phospholipase $\mathrm{C}$ activation in endothelial cells. In the present study, the phospholipase $\mathrm{C}$ inhibitors U73122 and NCDC nearly completely eliminated ACh-induced hyperpolarization. Our findings clearly indicate that ACh-induced hyperpolarization is closely associated with the formation of hydrolysis products. Furthermore, this concurs with the widely held belief that $\mathrm{IP}_{3}$ formation triggers the release of $\mathrm{Ca}^{2+}$ from intracellular stores (Berridge, 1993). Pretreatment with TSG or CPA, to deplete intracellular $\mathrm{Ca}^{2+}$ stores, also abolished ACh-induced hyperpolarization. These results imply that the intracellular $\mathrm{Ca}^{2+}$ pool mobilized by TSG or CPA in endothelial cells includes the $\mathrm{IP}_{3}$-sensitive $\mathrm{Ca}^{2+}$ pool.

The existence of a caffeine-sensitive $\mathrm{Ca}^{2+}$ pool, which is different from the $\mathrm{IP}_{3}$-sensitive $\mathrm{Ca}^{2+}$ pool, in endothelial cells has been suggested (Chen \& Cheung, 1992). It has now been demonstrated that the ryanodine receptor functions as a $\mathrm{Ca}^{2+}$. release channel in this caffeine-sensitive $\mathrm{Ca}^{2+}$ pool (McPherson et al., 1991; Bezprozvanny et al., 1991). The ryanodine-sensitive $\mathrm{Ca}^{2+}$ stores may operate as a part of an agonist-sensitive intracellular $\mathrm{Ca}^{2+}$ pool (Ziegelstein et al., 1994). In this study, when the caffeine-sensitive pool was depleted by long exposure to caffeine, the hyperpolarizing response to $\mathrm{ACh}$ was found to be markedly suppressed. An inhibitory action of caffeine on ACh-induced hyperpolarization has been found by other investigators (Chen \& Suzuki, 1990; Chen \& Cheung, 1992). However, it seems unlikely that a caffeine-sensitive $\mathrm{Ca}^{2+}$-induced $\mathrm{Ca}^{2+}$ release mechanism contributes to the increase in $\left[\mathrm{Ca}^{2+}\right]_{\mathrm{i}}$ resulting in the release of EDHF in response to ACh. We found that pretreatment with ryanodine, which is believed to abolish the capacity of the caffeine-sensitive pool to hold $\mathrm{Ca}^{2+}$ in smooth muscle cells (Iino, 1990), had no effect on ACh-induced hyperpolarization. One possible explanation for the inhibition by caffeine of ACh-induced hyperpolarization may be related to its action as a phosphodiesterase inhibitor (Leijten \& van Breemen, 1984). Agents that elevate intracellular 3':5'-cyclic monophosphate (cyclic AMP) have been shown to reduce $\left[\mathrm{Ca}^{2+}\right]_{\mathrm{i}}$ in endothelial cells (Parsaee et al., 1992). We observed that the phosphodiesterase inhibitor IBMX significantly attenuated ACh-induced hyperpolarization. Thus, the increased level of cyclic AMP may reduce AChstimulated rises in $\left[\mathrm{Ca}^{2+}\right]_{\mathrm{i}}$ in endothelial cells, thereby affecting the biosynthetic pathways of EDHF. An alternative explanation is that caffeine may have a direct effect on the membrane currents in smooth muscles. Caffeine has been shown to block voltage-dependent $\mathrm{Ca}^{2+}$ channels (Hughes et al., 1990) and affect many other ionic channels including $\mathrm{K}^{+}$channels (Akaike \& Sadoshima, 1989). Thus, caffeine might directly modify the $\mathrm{K}^{+}$channel which is involved in ACh-induced endothelium-dependent hyperpolarization. Finally, we cannot exclude the possibility that caffeine inhibits $\mathrm{IP}_{3}$-induced $\mathrm{Ca}^{2+}$ release from intracellular stores (Hirose et al., 1993).

Altogether our data support the notion that ACh-induced hyperpolarization is largely dependent on $\mathrm{Ca}^{2+}$ release from the $\mathrm{IP}_{3}$ sensitive $\mathrm{Ca}^{2+}$ pool. However, it should be kept in mind that, in the presence of the phospholipase $\mathrm{C}$ inhibitors or the endoplasmic reticulum $\mathrm{Ca}^{2+}$-pump ATPase inhibitors, ACh failed to generate the later sustained hyperpolarization, which is considered to be mediated by transmembrane $\mathrm{CA}^{2+}$ influx. As demonstrated in our recent study (Fukao et al., 1995a), TSG and CPA caused a relatively sustained endothelium-dependent hyperpolarization which was abolished in $\mathrm{Ca}^{2+}$-free medium. We have interpreted the results with TSG and CPA to indicate that both TSG and CPA deplete intracellular $\mathrm{Ca}^{2+}$ stores in endothelial cells and the emptying of the $\mathrm{Ca}^{2+}$ stores generates an intracellular signal to trigger $\mathrm{Ca}^{2+}$ influx from the extracellular medium, thereby leading to the generation of an endothelium-dependent hyperpolarization (Fukao et al., 1995a). Thus, if $\mathrm{IP}_{3}$-induced $\mathrm{Ca}^{2+}$ release from intracellular stores precedes $\mathrm{Ca}^{2+}$ influx from the extracellular medium, ACh-activated $\mathrm{Ca}^{2+}$ influx could no longer occur when the $\mathrm{IP}_{3}$-sensitive $\mathrm{Ca}^{2+}$ pool had been depleted with TSG or CPA.

One may argue that ACh could generate a second messenger responsible for transmembrane $\mathrm{Ca}^{2+}$ influx as a consequence of phospholipase $\mathrm{C}$ activation. It has been proposed that $\mathrm{IP}_{4}$, possibly in conjunction with the presence of $\mathrm{IP}_{3}$, is integral to the later and typically sustained influx of external $\mathrm{Ca}^{2+}$ (Berridge, 1993). Recently, $\mathrm{IP}_{4}$ has been shown to open $\mathrm{Ca}^{2+}$-permeate channels in membranes isolated from endothelial cells (Lückhoff \& Clapham, 1992). In this regard, it is unlikely that $\mathrm{Ca}^{2+}$ influx required for ACh-induced EDHF release is directly regulated by inositol phosphates, because the generation of sustained hyperpolarization by ACh was completely dependent on the extent of filling on intracellular $\mathrm{Ca}^{2+}$ stores. Furthermore, the involvement of protein kinase $\mathrm{C}$ subsequent to phospholipid hydrolysis is ruled out by the small effect of staurosporine, a putative protein kinase $\mathrm{C}$ inhibitor (Tamaoki et al., 1986), on ACh-induced sustained hyperpolarization. Staurosporine at the concentration used in this study nearly completely inhibited the contraction induced by the protein kinase $\mathrm{C}$ activators phorbol esters in rat mesenteric 
artery, as previously demonstrated in rat aorta (Hattori et al., 1995). Hence, it seems most likely that phospholipase C inhibitors suppress ACh-induced sustained hyperpolarization simply by blocking the initiation of $\mathrm{IP}_{3}$ formation and subsequently hindering $\mathrm{IP}_{3}$-induced depletion of intracellular $\mathrm{Ca}^{2+}$ pools. The inhibitory effects of TSG, CPA and U-73122 on ACh-induced hyperpolarization are not a result of a direct action on $\mathrm{K}^{+}$channel in smooth muscle cells, because the hyperpolarizing response to pinacidil, an endothelium-independent $\mathrm{K}^{+}$channel opener (Fukao et al., 1995b), was not modified by these agents.

ACh-activated $\mathrm{Ca}^{2+}$ entry for EDHF release appears to occur exclusively via a nifedipine-insensitive pathway. This finding is consistent with the lack of L-type $\mathrm{Ca}^{2+}$ channels in endothelial cells of conducting vessels (Himmel et al., 1993). The possible pathway for $\mathrm{Ca}^{2+}$ entry into endothelial cells is thought to be nonspecific cation channels (Nilius, 1990). It has been shown that depletion of intracellular $\mathrm{Ca}^{2+}$ stores by TSG and CPA activates nonspecific cation channels in human umbilical vein endothelial cells (Gericke et al., 1993; Zhang et al., 1994). In the presence of $\mathrm{Ni}^{2+}$ or $\mathrm{Mn}^{2+}$, ACh produced only a transient hyperpolarization which was similar to that obtained in $\mathrm{Ca}^{2+}$-free medium. In view of the concept that the $\mathrm{Ca}^{2+}$ entry activated by TSG and CPA is indistinguishable from the influx activated by receptor-mediated mechanisms in endothelial cells (Dolor et al., 1990), it may be possible that $\mathrm{Ni}^{2+}$

\section{References}

AKAIKE, N. \& SADOSHIMA, J. (1989). Caffeine affects four different ionic currents in the bullfrog sympathetic neurone. J. Physiol., 412, $221-244$.

BÉNY, J-L. \& BRUNET, P.C. (1988). Neither nitric oxide nor nitroglycerin accounts for all the characteristics of endothelially mediated vasodilation of pig coronary arteries. Blood Vessels, 25, $308-311$.

BERRIDGE, M.J. (1993). Inositol trisphosphate and calcium signalling. Nature, 361, 315-325.

BEZPROZVANNY, I., WATRAS, J. \& EHRLICH, B.E. (1991). Bellshaped calcium-response curves of $\operatorname{Ins}(1,4,5) \mathrm{P}_{3^{-}}$and calciumgated channels from endoplasmic reticulum of cerebellum. Nature, 351, $751-754$.

BRAYDEN, J.E. (1990). Membrane hyperpolarization is a mechanism of endothelium-dependent cerebral vasodilation. Am. J. Physiol., 259, H668-H673.

CHEN, G. \& CHEUNG, D.W. (1992). Pharmacological distinction of the hyperpolarization response to caffeine and acetylcholine in guinea-pig coronary endothelial cells. Eur. J. Pharmacol., 223, $33-38$.

CHEN, G. \& SUZUKI, H. (1990). Calcium dependency of the endothelium-dependent hyperpolarization in smooth muscle cells of the rabbit carotid artery. J. Physiol., 421, 521-534.

COLDEN-STANFIELD, M., SCHILLING, W.P., RITCHIE, A.K., ESKIN, S.G., NAVARRO, L.T. \& KUNZE, D.L. (1987). Bradykinin-induced increases in cytosolic calcium and ionic currents in cultured bovine aortic endothelial cells. Circ. Res., 61, 632-640.

DANTHULURI, N.R., CYBULSKY, M.I. \& BROCK, T.A. (1988). AChinduced calcium transients in primary cultures of rabbit aortic endothelial cells. Am. J. Physiol., 255, H1549-H1553.

DOLOR, R.J., STRAUSS, H.C. \& WHORTON, A.R. (1990). Mechanism of calcium influx in endothelial cells: role of intracellular calcium. Trans. Assoc. Am. Physicians, 103, 38-47.

FUKAO, M., HATTORI, Y., KANNO, M., SAKUMA, I. \& KITABATAKE, A. (1995a). Thapsigargin- and cyclopiazonic acid-induced endothelium-dependent hyperpolarization in rat mesenteric artery. Br. J. Pharmacol., 115, 987-992.

FUKAO, M., HATTORI, Y., KANNO, M., SAKUMA, I. \& KITABATAKE, A. (1995b). Evidence for selective inhibition by lysophosphatidylcholine of acetylcholine-induced endotheliumdependent hyperpolarization and relaxation in rat mesenteric artery. Br. J. Pharmacol., 116, $1541-1543$.

FURCHGOTT, R.F. \& VANHOUTTE, P.M. (1989). Endotheliumderived relaxing and contracting factors. FASEB J., 3, 20072018. and $\mathrm{Mn}^{2+}$ block the $\mathrm{Ca}^{2+}$ influx pathway through nonspecific cation channels, thereby causing ACh-induced hyperpolarization to be transient. However, the mechanism for $\mathrm{Ca}^{2+}$ entry may involve $\mathrm{Na}^{+}-\mathrm{Ca}^{2+}$ exchange, because $\mathrm{Ni}^{2+}$ is known to block the $\mathrm{Na}^{+}-\mathrm{Ca}^{2+}$ exchange current (Kimura et al., 1986). The involvement of $\mathrm{Na}^{+}-\mathrm{Ca}^{2+}$ exchange in $\mathrm{ACh}$-induced $\mathrm{Ca}^{2+}$ entry in endothelial cells is uncertain, but, if important, it must be activated in response to mobilization of intracellular $\mathrm{Ca}^{2+}$ stores.

In summary, this study demonstrates the importance of an elevation of endothelial $\left[\mathrm{Ca}^{2+}\right]_{i}$ in ACh-induced EDHF release from endothelial cells and the resulting hyperpolarization of smooth muscle cells of the rat mesenteric artery. The initial and transient component of the ACh-induced hyperpolarization appears to be related to $\mathrm{Ca}^{2+}$ release from an $\mathrm{IP}_{3}$-sensitive $\mathrm{Ca}^{2+}$ pool, whereas the late and sustained component of hyperpolarization is probably associated with activation of a $\mathrm{Ni}^{2+}$ - and $\mathrm{Mn}^{2+}$-sensitive $\mathrm{Ca}^{2+}$ influx mechanism other than L-type $\mathrm{Ca}^{2+}$ channels, which is presumably initiated by $\mathrm{IP}_{3-}$ induced depletion of the pool.

This work was supported in part by a Grant-in-Aid for Science Research from the Ministry of Education, Science, Sports and Culture of Japan and by the MITSUI Life Social Welfare Foundation.
GARLAND, C.J., PLANE, F., KEMP, B.K. \& COCKS, T.M. (1995). Endothelium-dependent hyperpolarization: a role in the control of the vascular tone. Trends Pharmacol. Sci., 16, 23-30.

GEORGER, D.E., RILEY, R.T., DORNER, J.W. \& COLE, R.J. (1988). Cyclopiazonic acid inhibition of the $\mathrm{Ca}^{2+}$-transport ATPase in rat skeletal muscle sarcoplasmic reticulum vesicles. Biochem. Pharmacol., 37, $978-981$.

GERICKE, M., DROOGMANS, G. \& NILIUS, B. (1993). Thapsigargin discharges intracellular calcium stores and induces transmembrane currents in human endothelial cells. Pflügers Arch., 422, $552-557$.

GRAIER, W.F., SCHMIDT, K. \& KUKOVETZ, W.R. (1992). Is the bradykinin-induced $\mathrm{Ca}^{2+}$ influx and the formation of endothelium-derived relaxing factor mediated by a $\mathrm{G}$ protein? Eur. $J$. Pharmacol., 225, 43-49.

HALLAM, T.J. \& PEARSON, J.D. (1986). Exogenous ATP raises cytoplasmic free calcium in fura-2 loaded piglet aortic endothelial cells. FEBS Letters, 207, 95-99.

HALLAM, T.J., PEARSON, J.D. \& NEEDHAM, L.A. (1988). Thrombinstimulated elevation of human endothelial-cell cytoplasmic free calcium concentration causes prostacyclin production. Biochem. J., 251, 243-249.

HATTORI, Y., KAWASAKI, H., FUKAO, M. \& KANNO, M. (1995). Phorbol esters elicit $\mathrm{Ca}^{2+}$-dependent delayed contractions in diabetic rat aorta. Eur. J. Pharmacol., 279, $51-58$.

HIMMEL, H.M., WHORTON, A.R. \& STRAUSS, H.C. (1993). Intracellular calcium, currents, and stimulus-response coupling in endothelial cells. Hypertension, 21, 112-127.

HIROSE, K., IINO, M. \& ENDO, M. (1993). Caffeine inhibits $\mathrm{Ca}^{2+}$ mediated potentiation of inositol 1,4,5-trisphosphate-induced $\mathrm{Ca}^{2+}$ release in permeabilized vascular smooth muscle cells. Biochem. Biophys. Res. Commun., 194, $726-732$.

HUGHES, A.D., HERING, S. \& BOLTON, T.B. (1990). The action of caffeine on inward barium current through voltage-dependent calcium channels in single rabbit ear artery cells. Pflügers Arch., 416, $462-466$.

HWANG, K.S. \& VAN BREEMEN, C. (1987). Ryanodine modulation of ${ }^{45} \mathrm{Ca}$ efflux and tension in rabbit aortic smooth muscle. Pflügers Arch., 408, 343-350.

IINO, M. (1990). Calcium release mechanisms in smooth muscle. Jpn. J. Pharmacol., 54, 345-354.

KIMURA, J., NOMA, A. \& IRISAWA, H. (1986). Na-Ca exchange current in mammalian heart cells. Nature, 319, 596-597. 
KOMORI, K., LONRENZ, R.R. \& VANHOUTTE, P.M. (1988). Nitric oxide, ACh, and electrical and mechanical properties of canine arterial smooth muscle. Am. J. Physiol., 255, H207- H212.

LEIJTEN, P.A. \& VAN BREEMEN, C. (1984). The effects of caffeine on the noradrenaline-sensitive calcium store in rabbit aorta. $J$. Physiol., 357, $327-339$

LESH, R.E., MARKS, A.R., SOMLYO, A.V., FLEISCHER, S. \& SOMLYO, A.P. (1993). Anti-ryanodine receptor antibody binding sites in vascular and endocardial endothelium. Circ. Res., 72, $481-488$.

LONG, C.J. \& STONE, T.W. (1985). The release of endotheliumderived relaxing factor is calcium dependent. Blood Vessels, 22, $205-208$.

LÜCKHOFF, A., POHL, U., MULSCH, A. \& BUSSE, R. (1988). Differential role of extra- and intracellular calcium in the release of EDRF and prostacyclin from cultured endothelial cells. $\mathrm{Br} . J$. Pharmacol., 95, 189-196.

LÜCKHOFF, A. \& CLAPHAM, D.E. (1992). Inositol 1,3,4,5-tetrakisphosphate activates an endothelial $\mathrm{Ca}^{2+}$-permeable channel. Nature, 355, 356-358.

MARTIN, W., VILLANI, G.M., JOTHIANANDAN, D. \& FURCHGOTT, R.F. (1985). Selective blockade of endothelium-dependent and glyceryl trinitrate-induced relaxation by haemoglobin and methylene blue in the rabbit aorta. J. Pharmacol. Exp. Ther., 232, $708-716$

MCPHERSON, P.S., KIM, Y.K., VALDIVIA, H., KNUDSON, C.M., TAKEKURA, H., FRANZINI-ARMSTRONG, C., CORONADO, R. \& CAMPBELL, K.P. (1991). The brain ryanodine receptor: a caffeine-sensitive calcium release channel. Neuron, 7, 17-25.

MOORE, P.K., AL-SWAYEH, O.A., CHONG, N.W., EVANS, R.A. \& GIBSON, A. (1990). L- $N^{\mathrm{G}}$-nitro arginine (L-NOARG), a novel, Larginine-reversible inhibitor of endothelium-dependent vasodilation in vitro. Br. J. Pharmacol., 99, 408-412.

NAGAO, T. \& VANHOUTTE, P.M. (1992). Hyperpolarization as a mechanism for endothelium-dependent relaxations in the porcine coronary artery. J. Physiol., 445, 355-367.

NAKASHIMA, M. \& VANHOUTTE, P.M. (1993). Endothelin-1 and -3 cause endothelium-dependent hyperpolarization in the rat mesenteric artery. Am. J. Physiol., 265, H2137-H2141.

NATHANSON, N.M. (1987). Molecular properties of the muscarinic acetylcholine receptor. Ann. Rev. Neurosci., 10, 195-236.

NEWBY, A.C. \& HENDERSON, A.H. (1990). Stimulus-secretion coupling in vascular endothelial cells. Ann. Rev. Physiol., 52, $661-674$.

NILIUS, B. (1990). Permeation properties of a non-selective cation channel in human vascular endothelial cells. Pflügers Arch., 416, $609-611$.

PARSAEE, H., MCEWAN, J.R., JOSEPH, S. \& MACDERMOT, J. (1992). Differential sensitivities of the prostacyclin and nitric oxide biosynthetic pathways to cytosolic calcium in bovine aortic endothelial cells. Br. J. Pharmacol., 107, 1013-1019.
PEACH, M.J., SINGER, H.A., IZZO, N.J. \& LOEB, A.L. (1987). Role of calcium in endothelium-dependent relaxation of arterial smooth muscle. Am. J. Cardiol., 59, 35A-43A.

PUTNEY, J.W., Jr. (1986). A model for receptor-regulated calcium entry. Cell Calcium, 7, 1-12.

RANDRIAMAMPITA, C. \& TSIEN, R.Y. (1993). Emptying of intracellular $\mathrm{Ca}^{2+}$ stores releases a novel small messenger that stimulates $\mathrm{Ca}^{2+}$ influx. Nature, 364, 809-814.

SEIDLER, N.W., JONA, I., VEGH, M. \& MARTONOSI, A. (1989). Cyclopiazonic acid is a specific inhibitor of the $\mathrm{Ca}^{2+}$-ATPase of sarcoplasmic reticulum. J. Biol. Chem., 264, 17816-17823.

SMITH, R.J., SAM, L.M., JUSTEN, J.M., BUNDY, G.L., BALA, G.A. \& BLEASDALE, J.E. (1989). Receptor-coupled signal transduction in human polymorphonuclear neutrophils: Effects of a novel inhibitor of phospholipase C-dependent processes on cell responsiveness. J. Pharmacol. Exp. Ther., 253, 688-697.

SUZUKI, H., CHEN, G. \& YAMAMOTO, Y. (1992). Endotheliumderived hyperpolarizing factor (EDHF). Jpn. Circ. J., 56, 170173

TAMAOKI, T., NOMOTO, H., TAKAHASHI, I., KATO, Y., MORIMOTO, M. \& TOMITA, F. (1986). Staurosporine, a potent inhibitor of phospholipid $/ \mathrm{Ca}^{++}$dependent protein kinase. Biochem. Biophys. Res. Commun., 135, 397-402.

THASTRUP, O., CULLEN, P.J., DRØBAK, B.K., HANLEY, M.R. \& DOWSON, A.P. (1990). Thapsigargin, a tumor promotor, discharges intracellular $\mathrm{Ca}^{2+}$ stores by specific inhibition of the endoplasmic reticulum $\mathrm{Ca}^{2+}$-ATPase. Proc. Natl. Acad. Sci. U.S.A., 87, 2466-2470.

WALENGA, R., VANDERHOEK, J.Y. \& FEINSTEIN, M.B. (1980). Serine esterase inhibitors block stimulus-induced mobilization of arachidonic acid and phosphatidylinositide-specific phospholipase $\mathrm{C}$ activity in platelets. J. Biol. Chem., 55, 6024-6027.

WEBER, A. \& HERZ, R. (1968). The relationship between caffeine contracture of intact muscle and the effect of caffeine on reticulum. J. Gen. Physiol., 52, $750-759$.

WHORTON, A.R., WILlis, C.E., KENT, R.S. \& YOUNG, S.L. (1984) The role of calcium in the regulation of prostacyclin synthesis by porcine aortic endothelial cells. Lipids, 19, 17-24.

XIONG, Z.L., KITAMURA, K. \& KURIYAMA, H. (1991). ATP activates cationic currents and modulates the calcium current through GTP-binding protein in rabbit portal vein. J. Physiol., 440, $143-165$.

ZHANG, H., INAZU, M., WEIR, B., BUCHANAN, M. \& DANIEL, E (1994). Cyclopiazonic acid stimulates $\mathrm{Ca}^{2+}$ influx through nonspecific cation channels in endothelial cells. Eur. J. Pharmacol., 251, $119-125$.

ZIEGElSTEIN, R.C., SPURGEON, H.A., PILI, R., PASSANITI, A., CHENG, L., CORDA, S., LAKATTA, E.G. \& CAPOGROSSI, M.C. (1994). A functional ryanodine-sensitive intracellular $\mathrm{Ca}^{2+}$ store is present in vascular endothelial cells. Circ. Res., 74, 151-156.

(Received April 22, 1996 Revised November 15, 1996 Accepted December 11, 1996) 